Article

\title{
Analyzing the Impact of Agrophotovoltaic Power Plants on the Amenity Value of Agricultural Landscape: The Case of the Republic of Korea
}

\author{
Tae-Hwa Kim, Ki-Suk Chun and Seung-Ryong Yang *
}

check for

updates

Citation: Kim, T.-H.; Chun, K.-S.; Yang, S.-R. Analyzing the Impact of Agrophotovoltaic Power Plants on the Amenity Value of Agricultural Landscape: The Case of the Republic of Korea. Sustainability 2021, 13, 11325. https://doi.org/10.3390/su132011325

Academic Editors: Margarita Maria Brugarolas Molla-Bauza and Laura Martinez-Carrasco

Received: 12 September 2021 Accepted: 8 October 2021

Published: 13 October 2021

Publisher's Note: MDPI stays neutral with regard to jurisdictional claims in published maps and institutional affiliations.

Copyright: (c) 2021 by the authors. Licensee MDPI, Basel, Switzerland. This article is an open access article distributed under the terms and conditions of the Creative Commons Attribution (CC BY) license (https:// creativecommons.org/licenses/by/ $4.0 /)$.
Department of Food and Resource Economics, Korea University, Seoul 02841, Korea; kimth@korea.ac.kr (T.-H.K.); pon98128@korea.ac.kr (K.-S.C.)

* Correspondence: sryang@korea.ac.kr

\begin{abstract}
Recently, in Korea, there have been some disturbing events forcing a trade-off between the expansion of agrophotovoltaic (APV) power plants and the agricultural policy to enhance the public benefit function of agriculture. Under this context, this study attempts to examine the public perception of agricultural landscape and the APV power plants and to analyze the impact of APV power plants on the amenity value of the agricultural landscape. The results of the analysis based on the choice experiment method shows that the marginal willingness-to-pay for a rural tourism accommodation with a 'agricultural landscape view' is USD 64.37 higher compared to 'agrophotovoltaics panel view.' This implies that the value of the agricultural landscape decreases when solar panels are installed on farmland, signifying the detrimental impact of the APV power plants on the multi-functionality of agriculture. If the installation of APVs is expanded to farmlands nationwide, the amenity value of agricultural landscape is estimated to decrease by USD 1.70 billion or $55.0 \%$ of the total estimated amenity value in Korea.
\end{abstract}

Keywords: trade-off; agrophotovoltaics; agricultural landscape; multi-functionality of agriculture; choice experiment

\section{Introduction}

For every choice made, there is a sacrifice or opportunity cost that follows. In the process of formulating a government policy, it is often the case when one of the two policy goals is delayed or sacrificed in pursuit of accomplishing the other one in favor. In economics, such a phenomenon is defined as a 'trade-off' between the policies [1]. When a trade-off between two policy goals is expected, a thorough analysis of pros and cons of detailed alternatives is required to make an agreeable policy decision. If the government is unaware of and does not consider such trade-offs between the policy goals before making a decision, social dilemma and social cost may incur from the enforced policy or measures.

Recently, in the Republic of Korea (hereafter Korea), some disturbing events have been unfolding, involving a trade-off between two policy goals. The problem in question is an inevitable trade-off relationship between the expansion of agrophotovoltaic (APV) power plants implemented as part of the renewable energy expansion policy and the agricultural policy to expand the public benefit function of agriculture.

The APVs refers to the way of farming parallel to generating solar power by installing solar panel arrays on arable land and cultivating crops on the ground beneath the panel [2]. The Korean government is implementing APV projects in rural areas as part of the renewable energy expansion policies, the 'Renewable Energy 3020 Implementation Plan' and the '2050 Carbon Neutral Strategy.' These strategies aim to enlarge the proportion of renewable energy up to $20 \%$ by 2030 and to increase the renewable power generation capacity up to 63.8 GW, of which 10.0 GW are generated from rural solar panels [3]. In 2020, 8072 solar power plants $(1.2 \mathrm{GW})$ were installed in rural areas across the country, of which $10(833 \mathrm{Kw})$ 
were APVs [4]. $10 \mathrm{APVs}$ are currently being piloted at nationwide, and the extent of rural areas allocated to solar power plants, including APVs, has increased from 42 ha in 2010 to 2555 ha (approximately $0.2 \%$ compared to total agricultural lands) in 2019. Currently, the Korean government aims to expand APVs to reach the target level by 2030 [5].

As for the public benefit function of agriculture, on the other hand, the public benefit direct payment system was initiated in Korea in 2020 and provides direct payments to rural residents and farmers contributing to creating public benefits. Such benefits include preserving the environment, stable food supply, maintaining rural communities through agricultural activities, and enhancing agricultural landscape.

Recently, members of the National Assembly from the ruling party proposed an amendment of the Farmland Act that would enable the installation and operation of APV power plants in agricultural promotion areas. The currently enacted Farmland Act restrictively allows the installation of APV power plants to farmland in the non-agricultural promotion areas as well as in the agricultural protection areas (excluding the agricultural promotion zone) for a period of eight years. The proposed amendment of the Farmland Act mainly aims to expand the business period to 20 years, and it allows the installation of APV facilities in the agricultural promotion areas, which are land-use restricted zones. Supporters of the APVs expansionary policy emphasize the potential benefits of APV systems with respect to the preservation of farmlands as well as the creation of stable income source for farm households. Moreover, the same group of people assure the farmers that the difference in both quantity and quality of agricultural products produced from APV solar farms are indifferent in comparison to those produced from general farmland. Under this policy, solar panels are installed in arable land where agricultural cultivation takes place beneath the panels so that both agricultural activities and solar power generation are simultaneously pursued [6]. The proponents consider APVs as an efficient means to produce both food and energy especially in the midst of increasing competition over arable land [7].

A vehement protest against to the revision of Farmland Act came from farmers' groups. The opponents claim that agricultural promotion areas are the last stand for securing food security which is vital considering that Korea is only $21.0 \%$ self-sufficient in staple crops as of 2019. They also worry that public benefits generated from agriculture, including preserving environmental ecology and pleasant rural agricultural environments, would be compromised.

Besides Korea, APV systems have been deployed, piloted and studied in the European Union (Germany, Italy, France, Spain, etc.), the United States, Chile, Japan, China, and India $[8,9]$. Especially in Korea, however, the escalation of social conflicts over the proposed installation of APV power plants in agricultural promotion areas is ongoing. Previous studies on the development of APV power plants can be generally classified as follows. First, studies on the analysis of the present situations, as well as various aspects of photovoltaic (PV) power plant systems and APVs [6,10-15]. Second, analytic studies on the economic viability of the APV business and its impact on rural household income [16-18]. Third, studies attempting to estimate yields and quality of harvested crops produced under the solar panels. The impacts of APV shading on various crops, such as cabbage, coffee, cotton, garlic, kiwi, maize, mango, napa cabbage, onion, potato, rice, sesame, sunflower, wheat, etc., have been researched globally, including in Argentina, Belgium, China, France, India, Korea, USA, etc. $[5,12,16,18-22]$. There are several studies that tried to address rising concerns related to the impact of APVs on the agricultural landscape and public acceptance towards the installation of APVs [23-25].

A trade-off between the two policies, the expansion of the APV systems and the public benefit direct payment scheme, is inevitable. However, previous studies on APVs are skewed towards assessing economic benefits and costs of the system installation. So far, none of the studies have attempted to analyze the empirical effect of APV systems on the amenity value of the agricultural landscape.

Against this backdrop, this paper attempts to estimate the impact of the APV power plant installation on the public benefit function of agriculture with a particular focus on the amenity value of the agricultural landscape in Korea. To this end, survey was conducted 
on the public awareness of the agricultural landscape and APVs, which was employed following the paired comparison choice experiment method. Despite the heightening dispute over the incompatible trade-off between the energy policy and agricultural policy in Korea, to the best of our knowledge, this study is pioneering in analyzing the effect of APV systems vis-à-vis the amenity value of the agricultural landscape.

The rest of this paper is organized as follows. Section 2 explains the methodological framework, including survey designs and the analytic model. Section 3 presents the results of the analyses. Section 4 discusses policy implications on the direction of APV projects, and Section 5 concludes with a summary of key findings.

\section{Methodological Framework}

\subsection{Research Design for a Survey of Public Awareness on Agriculture Landscape Resources and APVS}

The analysis in this study is based on the data obtained from a questionnaire survey conducted in Korea from September 1 to 9, 2020, by a specialized survey agency. The final sample included 500 males and females aged 19 years or above. Proportionate sampling was used to ensure that the samples are representatives of region, gender and age. The survey questions and the analysis methodology were reviewed through three rounds of preliminary surveys and expert consultations before the distribution of the actual survey. This survey comprised of two parts. The first part is about the public awareness towards agricultural landscape resources and APVs, and the second part is a paired comparisonbased preference test.

Questionnaires included in the first part of the survey, the survey of public awareness, can be classified into three major categories. The first set of questions surveyed the awareness of the public benefit function of agriculture and landscape resources. Respondents were then asked number of questions related to their awareness of the functions and future values of agriculture and rural areas. The last part of the awareness survey asked about how the respondents regard the importance of the renewable energy expansion policy and the dissemination of APVs, respectively.

A five-point Likert scale was used to measure respondents' attitudes towards the level of contribution of domestic agriculture as well as the creation and preservation of the amenity value of the agricultural landscape. The questions related to the awareness of the public benefit functions and future values of agricultural and rural areas were asked based on the two-point rating scale of agree or disagree.

The level of awareness on the importance of the renewable energy expansion policy was surveyed using a five-point Likert scale, and respondents were also asked whether they agree or disagree on the statement that APV expansion in rural areas would be detrimental to the agricultural landscape. The survey provided general descriptions of the renewable energy policy and the APV policy assisted by image data such as Figure 1.

\subsection{The Choice Experiment (CE) Model}

\subsubsection{Theoretical Background}

The CE method employed in this study to evaluate the impact of the APV installation on agricultural landscape value is based on the characteristics model [26]. The model was developed to determine the value or utility of specific goods or services in terms of characteristics or attributes inherent in those products. This method, therefore, guides respondents to choose their most preferred alternatives given descriptions of specific goods by their attributes and the levels of attributes [27].

The CE method was further developed by several researchers including [28,29]. It is applied in various fields, such as environment, agriculture, transportation, tourism, housing, and healthcare, as a method to evaluate the values of general goods and noncommodities [27,30-35]. 


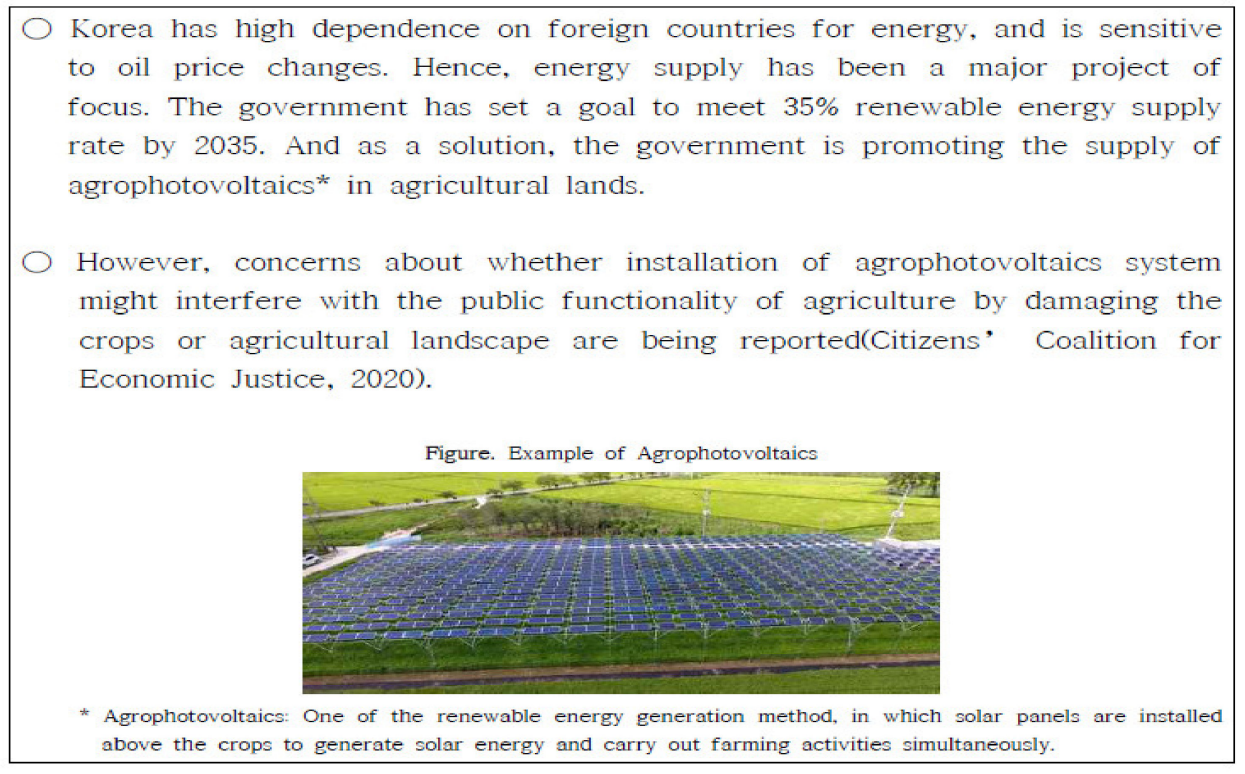

Figure 1. Descriptions provided in the survey.

In valuing the landscape, the most commonly used technique is the CVM (contingent valuation method), but one limitation of this method is that it only estimates the economic value based on respondents' perceived value. Unlike the CVM, the CE method has advantages in that it can estimate the use or nonuse value based on various attributes and attribute levels embodied in alternatives. Moreover, the CE method allows the estimation of the part-worth and the marginal willingness-to-pay (MWTP) [32,36]. In addition, the CE method has the advantage of providing alternatives that may not actually exist to reveal the consumers' preferences.

\subsubsection{Analytic Model}

The CE model is based on the random utility theory. In the random utility model, when $J$ number of alternatives is given to respondent $i$, the utility experienced by $j^{\text {th }}$ choice $\left(U_{i j}\right)$ represents the preference of the respondent when selecting from alternatives. The $U_{i j}$ is comprised of the deterministic utility $\left(V_{i j}\right)$ and stochastic utility $\left(\epsilon_{i j}\right)$ as expressed in Equation (1). The deterministic utility $\left(V_{i j}\right)$ can be expressed as Equation (2) which captures the relative size of the utility $(\beta)$ generated from $N$ number of attributes $(X)$, assuming a linear relationship.

$$
\begin{gathered}
U_{i j}=V_{i j}+\epsilon_{i j} \\
\text { where } i=1,2, I, j=1,2, J \\
V_{i j}=\sum_{n=1}^{N} \beta_{i j n} X_{i j n}
\end{gathered}
$$

Utility $U_{i j}$ represents the preference of respondents. If a respondent has a higher preference for the $j^{\text {th }}$ alternative than the $k^{\text {th }}$ alternative, the respondent would then select the alternative $j$. Then, the utility function of the respondent $i$ becomes $U_{i j}>U_{i k}(k \in$ $\left.J_{\mathrm{i}}, k \neq j\right)$, and the chance the respondent $i$ selects the alternative $j, P_{i j}$, can be expressed as Equation (3).

$$
\begin{array}{r}
P_{i j}=\operatorname{Pr}\left(U_{i j}>U_{i k}, k \neq j, k \in J\right) \\
=\operatorname{Pr}\left(V_{i j}-V_{i k}>\varepsilon_{i k}-\varepsilon_{i j}\right) \\
=\operatorname{Pr}\left(V_{i j}+\varepsilon_{i j}>V_{i k}+\varepsilon_{i k}\right)
\end{array}
$$

The chance of selection for each alternative provided to a respondent for each question can be expressed by the discrete choice model. Suppose that the distribution of the error 
term (stochastic utility) between the alternatives follows independence from irrelevant alternatives (IIA) and that the Weibull distribution follows the extreme value type 1 . In this case, the chance that respondent $i$ selects $j$ among $J$ number of alternatives, $P_{i j}$, can be expressed as Equation (4). The probability model derived based on such strict assumption is known as the multinomial logit model [27,37].

$$
P_{i j}=\frac{\exp \left(\mu V_{i j}\right)}{\sum_{j=1}^{J} \exp \left(\mu V_{i j}\right)}
$$

In Equation (4), $\mu$ is a scale that has an inverse relationship with the variance of the error term and can be assumed as 1 , representing constant error variance. Moreover, $V_{i j}$, the deterministic utility is assumed as a linear function in Equation (2) and can be expressed as Equation (5) in the multinomial logit model.

$$
V_{i j}=\beta_{0}+\beta_{1} X_{i j \text { landscape }}+\beta_{2} X_{i j \text { convenience }}+\beta_{3} X_{i j \text { cleanliness }}+\beta_{4} X_{i j} \text { price }
$$

$X_{i j n}$ is the $n^{\text {th }}$ attribute of choice $j$ selected by the respondent $i$, and $\beta$ is the parameter of each attribute. Each attribute's part-worth and the MWTP for each level of increase in an attribute can be estimated from Equation (2). MWTP can be calculated as Equation (6) where $X_{n}$ represents the respondent for the $\mathrm{n}^{\text {th }}$ attribute variable, and $X_{p}$ is the price variable.

$$
\operatorname{MWTP}_{X_{n}}=\frac{d V / d X_{n}}{d V / d X_{p}}=-\frac{\beta_{n}}{\beta_{p}}
$$

\subsection{Research Design for the Choice Experiment}

\subsubsection{Determining the Target Goods of the Experiment}

In this study, the agricultural landscape refers to both tangible and intangible resources that provide ecological, recreational and aesthetic values that are produced as joint-products of various agricultural activities [38]. Hence, the agricultural landscape is one of the numerous benefits generated from agriculture (i.e., multi-functionality of agriculture), as well as a joint-product and non-commodity good which exhibits characteristics of externality and public goods.

The agricultural landscape is being considered as an essential element of rural tourism and an important attribute for the choice of tourist accommodation in rural areas [39,40]. Thus, this study specifically hypothesizes a real-life scenario of choosing an accommodation for rural tourism. The effect of APVs on the amenity value of the agricultural landscape was analyzed based on the CE model taking the agricultural landscape as an attribute of rural tourism accommodation. The levels of agricultural landscape were divided into 'solar panel view' and 'farmland view,' and the level of price attribute, which is used as a reference for estimating the marginal willingness-to-pay (MWTP), was set as the market price for accommodation to estimate the monetary value of the agricultural landscape.

\subsubsection{Determining the Attributes and Attribute Levels}

Determining the appropriate attributes and their levels is critical in applying the $\mathrm{CE}$ model. This task not only represents the uniqueness of the $\mathrm{CE}$, but also ensures the reliability of the results $[27,34]$. In this study, we selected the attributes that are mutually independent to satisfy the IIA assumption of the logit model $[36,41,42]$. In addition, the attributes were selected with consideration to the previous research $[39,40,43-49]$. When evaluating the values of attributes of general commodities using the CE method, the market price is usually taken as a reference to set the price level. However, when the CE method is applied to evaluate the value of non-commodities, setting an appropriate price level becomes critical in order to estimate a rational MWTP. Previous studies tend to rely on expert consultations to estimate hypothetical prices and apply the estimated prices as the price attribute levels. However, discussions regarding the validity and credibility of such 
imaginary price levels derived from expert surveys are ongoing. We tried to set reliable and valid levels of the price attribute [32,50,51]. As shown in Equation (6), the MWTP of each attribute is determined by the price attribute, and hence the price attribute levels employed should be valid and reflect reality.

This study adopted the attributes and attribute levels as demonstrated in Table 1. To do so, factors affecting the choice of tourism accommodation, including rural tourism, were analyzed, and previous studies on choice attributes of accommodation were reviewed to derive the major attributes. Following the principle of mutual independence among attributes, the attributes for accommodation were selected as 'view type,' 'in-room amenities,' 'cleanliness of the room', and 'price'.

The major attribute 'view type' was divided into sub-levels of 'solar panel view' and 'farmland view.' Regarding the attribute 'in-room amenities,' four kinds of hotel amenities were provided, and the attribute levels were classified as 'low (1 of 4), ' 'moderate (3 of 4)' and 'high (include all).' The levels of 'cleanliness of the room' were divided into 'average,' 'clean (3-star hotel level)' and very clean.' Taking the accommodation price derived from a survey conducted by [39] and the market price data into consideration, the price attribute was divided into sub-levels of 'USD 50.90 (KRW 60,000), ' USD 76.35 (KRW 90,000), ' 'USD 101.80 (KRW 120,000),' and 'USD 127.25 (KRW 150,000).' The price unit presented in the survey was KRW. However, throughout this study, all the monetary values in KRW were converted into USD based on the exchange rate as of September 2020 which corresponds to $1178.80 \mathrm{KRW} / \mathrm{USD}$.

Table 1. Attributes and attribute levels of rural tourism accommodation.

\begin{tabular}{ccc}
\hline Attribute & Attribute Levels & $\begin{array}{c}\text { Number } \\
\text { of Levels }\end{array}$ \\
\hline View type & Solar panel view (ref.) $/$ Farmland view & 2 \\
In-room & Low (ref.) $/$ Moderate/High & 3 \\
amenities & Average (ref.) $/$ Clean $/$ Very clean & 3 \\
Cleanliness & $\$ 50.90($ KRW 60,000) $/ \$ 76.35($ KRW 90,000) $/ \$ 101.80(\mathrm{KRW}$ & 4 \\
Price (per night) & $120,000) / \$ 127.25(\mathrm{KRW} 150,000)$ & \\
\hline
\end{tabular}

ref. denotes reference.

\subsubsection{Determining Choice Alternatives and Choice Sets}

Once the attributes and attribute levels are determined, confirming choice alternatives and choice sets is required. In this analysis, there are a total of 72 choice alternatives if we combine all the levels of each attribute. However, asking the respondents for their preference among such an extensive number of alternatives is unrealistic. Hence, we derived a minimum set of 16 choice alternatives by applying the orthogonal design using SPSS.

When making choices in real life, individuals sometimes face a difficulty in choosing one among possible alternatives and end up abandoning the effort of making a choice. For this reason, many previous studies that applied the CE method provided no-choice options like 'refuse to choose' in addition to 'Select A' or 'Select B' [52]. Such no-choice options are related to alternative specific constants, and the investigator can confirm the respondents' actual preference towards purchasing a particular product among several alternatives [32]

The survey was designed in a way that 16 choice sets are comprised of choice alternatives including no-choice options as presented in Figure 2. Moreover, image data were provided to effectively depict the visual differences between, e.g., the choice of accommodation with typical farmland view and APV view. 


\begin{tabular}{|c|c|c|c|}
\hline Attribute & Accomodation A & Accomodation B & No choice \\
\hline View type & & & \multirow{5}{*}{ No choice } \\
\hline & Farmland view & Solar panel view & \\
\hline In-room amenities & $\begin{array}{c}\text { Moderate } \\
\text { (3 amenities or below out of } 4 \text { ) }\end{array}$ & $\begin{array}{c}\text { High } \\
\text { (All included) }\end{array}$ & \\
\hline Cleanliness & Average & Very clean & \\
\hline Price (per night) & KRW 90,000/1night & KRW 150,000/1night & \\
\hline Choice & ( & ( & ) \\
\hline
\end{tabular}

Figure 2. Survey example of a question on the choice of accommodation during rural tourism.

\section{Results}

\subsection{Characteristics of the Survey Respodents}

The characteristics of the survey respondents are summarized in Table 2. Among the total of 500 respondents of the survey, $50.8 \%$ were male ( 254 respondents) and $49.2 \%$ were female (246 respondents). Considering age, $23.2 \%$ were in their $50 \mathrm{~s}$ (254 respondents), $22.6 \%$ were in their $40 \mathrm{~s}, 18.2 \%$ were in their $30 \mathrm{~s}, 18.0 \%$ were in their $20 \mathrm{~s}$, and $18.0 \%$ were 60 or above. As for the annual household income, the majority, 28.0\%, earned USD 16,966 to 33,933 annually, followed by USD 33,933 to 50,899 (26.0\%), USD 50,899 to $67,866(19.4 \%)$, below USD 16,966 (11.4\%), USD 67,866 to 84,832 (9.8\%), and above USD 84,832 (5.4\%).

As for occupation, company employees were the majority with $47.8 \%$, followed by homemakers $(12.2 \%)$, unemployed $(10.0 \%)$, others $(7.0 \%)$, self-employed $(6.2 \%)$, students $(6.2 \%)$, professional occupations $(6.2 \%)$, and government employees $(4.4 \%)$. As for the residential province, the residents of Gyeonggi/Gangwon/Incheon provinces were the majority (34.6\%), followed by Seoul (19.4\%), Gyeongnam/Busan (15.2\%), Gyeongbuk/Daegu (9.8\%), Chungnam/Cungbuk/Daejeon (9.6\%), Jeonnam/Jeonbuk/Gwangju (9.4\%), and Jeju (2.0\%). Urban residents comprised $88.6 \%$ of the sample (443 respondents) and $11.4 \%$ were non-urban residents (57 respondents).

Table 2. Characteristics of survey respondents (respondents, \%).

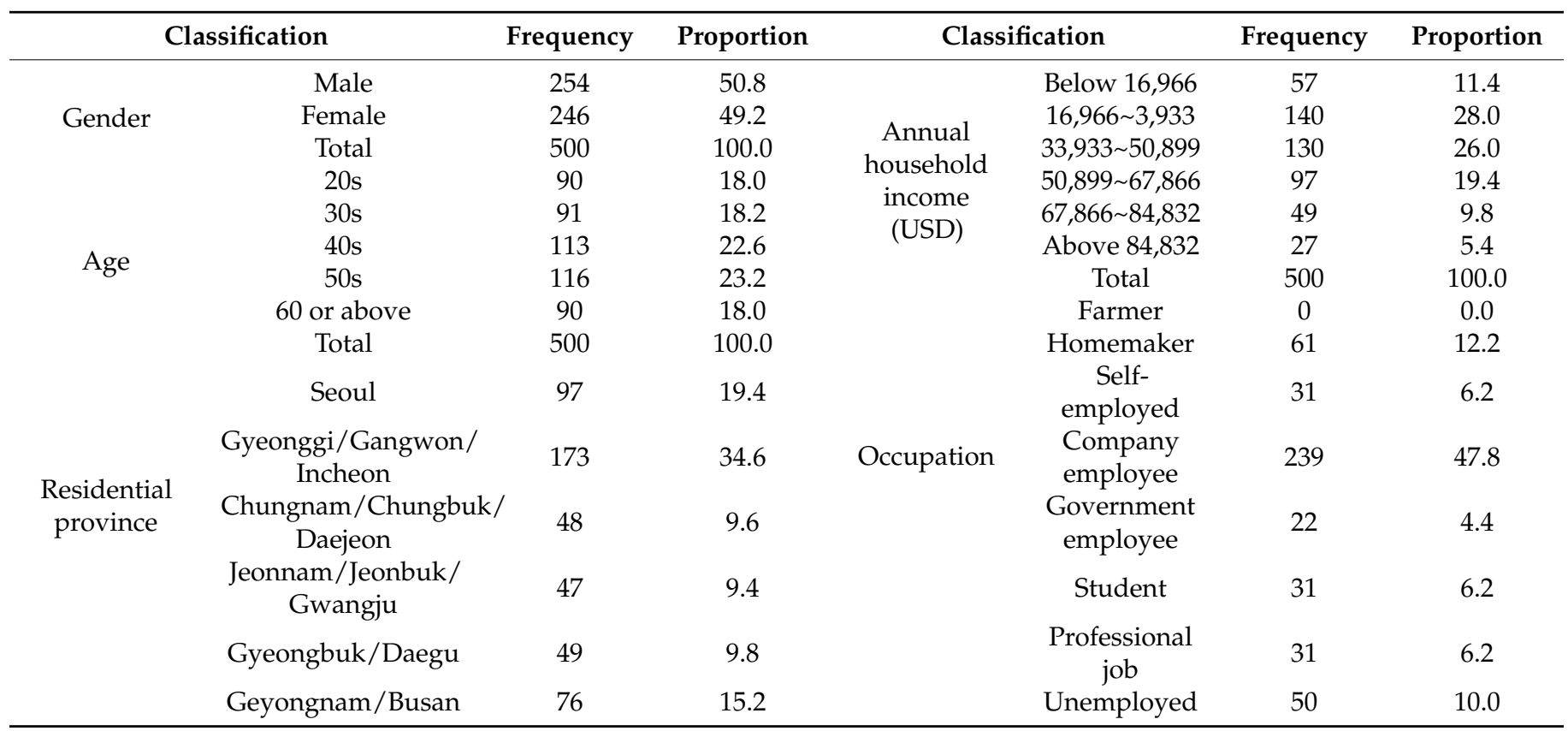


Table 2. Cont.

\begin{tabular}{|c|c|c|c|c|c|c|}
\hline \multicolumn{2}{|c|}{ Classification } & \multirow{2}{*}{$\begin{array}{c}\text { Frequency } \\
10\end{array}$} & \multirow{2}{*}{$\begin{array}{c}\text { Proportion } \\
2.0\end{array}$} & Classification & \multirow{2}{*}{$\begin{array}{c}\text { Frequency } \\
35\end{array}$} & \multirow{2}{*}{$\begin{array}{c}\text { Proportion } \\
7.0\end{array}$} \\
\hline & Jeju & & & Others & & \\
\hline & Total & 500 & 100.0 & Total & 500 & 100.0 \\
\hline & Urban & 443 & 88.6 & & & \\
\hline \multirow[t]{2}{*}{ Urban/Nonurban } & Nonurban & 57 & 11.4 & \multirow[t]{2}{*}{ Total } & 500 & 100.0 \\
\hline & Total & 500 & 100.0 & & & \\
\hline
\end{tabular}

The exchange rate of 1,178.80 KRW/USD was applied.

\subsection{Public Awareness of the Multifunctionality of Agriculture and APVs}

The first survey question asked respondents how important agriculture is with respect to its functions providing public benefits. The result is shown in Table 3. Among the total respondents, $87.0 \%$ (453 respondents) answered 'important.' In contrast, $0.6 \%$ (3 respondents) answered 'not important.' When the responses were converted into the 1-5 scale points, the average was 4.07 , implying that the majority of the citizens value the public benefit function of agriculture as important.

Table 3. The importance of public benefit functions of agriculture.

\begin{tabular}{cccccccc}
\hline Classification & $\begin{array}{c}\text { Not at All } \\
\text { Important }\end{array}$ & $\begin{array}{c}\text { Not } \\
\text { Important }\end{array}$ & Neutral & Important & $\begin{array}{c}\text { Very } \\
\text { Important }\end{array}$ & Total & Average \\
\hline $\begin{array}{c}\text { Frequency } \\
\text { (respondents) }\end{array}$ & 0 & 3 & 62 & 334 & 101 & 500 & 4.07 \\
$\begin{array}{c}\text { Proportion } \\
(\%)\end{array}$ & 0.0 & 0.6 & 12.4 & 66.8 & 20.2 & 100.0 & \\
\hline
\end{tabular}

The average was calculated by assigning points as follows: Not at all important $=1$ point; Not important $=2$ points; Neutral $=3$ points; Important $=4$ points; Very important $=5$ points.

The respondents were then asked how important are the landscape resources generated by agriculture. The result is as shown in Table 4 . The result shows that $87.0 \%$ (435 respondents) answered 'important,' whereas only $0.8 \%$ (four respondents) answered 'not important.' The average point total was 4.11 , which could infer that the majority of the citizens consider landscape resources provided by agriculture to be fairly important.

Table 4. The importance of agricultural landscape resources.

\begin{tabular}{cccccccc}
\hline Classification & $\begin{array}{c}\text { Not at All } \\
\text { Important }\end{array}$ & $\begin{array}{c}\text { Not } \\
\text { Important }\end{array}$ & Neutral & Important & $\begin{array}{c}\text { Very } \\
\text { Important }\end{array}$ & Total & Average \\
\hline $\begin{array}{c}\text { Frequency } \\
\text { (respondents) }\end{array}$ & 0 & 4 & 61 & 309 & 126 & 500 & 4.11 \\
$\begin{array}{c}\text { Proportion } \\
(\%)\end{array}$ & 0.0 & 0.8 & 12.2 & 61.8 & 25.2 & 100.0 & \\
\hline
\end{tabular}

The average was calculated by assigning points as follows: Not at all important $=1$ point; Not important $=2$ points; Neutral $=3$ points; Important $=4$ points; Very important $=5$ points.

The following question asked about the level of landscape resource produced by agriculture. The result indicates that $34.6 \%$ (173 respondents) of the total respondents answered 'slightly high,' whereas $22.8 \%$ (114 respondents) answered 'slightly low' (Table 5). When the results were converted to points, the average point total was 3.13 , which slightly exceeded the average value of 3.0. This result demonstrates that, although the respondents had a high regard for the importance of agricultural landscape resources, there was relatively low regard for the actual agricultural landscape produced by domestic farming. It can be interpreted that there is a discrepancy between public awareness regarding the importance of the landscape and the actual level of landscape provided. 
Table 5. Level of landscape resources produced by agriculture.

\begin{tabular}{cccccccc}
\hline Classification & $\begin{array}{c}\text { Very } \\
\text { Low }\end{array}$ & $\begin{array}{c}\text { Slightly } \\
\text { Low }\end{array}$ & Neutral & $\begin{array}{c}\text { Slightly } \\
\text { High }\end{array}$ & $\begin{array}{c}\text { Very } \\
\text { High }\end{array}$ & Total & Average \\
\hline $\begin{array}{c}\text { Frequency } \\
\text { (respondents) }\end{array}$ & 13 & 101 & 213 & 154 & 19 & 500 & 3.13 \\
Proportion $(\%)$ & 2.6 & 20.2 & 42.6 & 30.8 & 3.8 & 100.0 & \\
\hline
\end{tabular}

The average was calculated by assigning points as follows: Not at all important $=1$ point; Not important $=2$ points; Neutral $=3$ points; Important $=4$ points; Very important $=5$ points.

The survey subsequently asked the respondents about their awareness of agriculture and rural areas. The results are presented in Table 6. Among the respondents, 65.8\% (329 respondents) expressed that they could consider rural areas to spend their leisure time while $34.2 \%$ (171 respondents) answered they would not (Table 6). In addition, 90.2\% (451 respondents) answered 'yes' to the question of 'unsustainable development of the rural area is damaging the landscape,' and only $9.8 \%$ (49 respondents) answered 'no.' Moreover, $88.2 \%$ (441 respondents) answered 'yes' when asked if the importance of agricultural amenities such as the landscape values will increase in the future compared to today while $11.8 \%$ (59 respondents) answered 'no.'

Table 6. Awareness of agriculture and rural areas.

\begin{tabular}{|c|c|c|c|c|}
\hline Classification & & Yes & No & Total \\
\hline \multirow{2}{*}{$\begin{array}{l}\text { - Rural areas can be a place to spend leisure } \\
\text { time. }\end{array}$} & $\begin{array}{c}\text { Frequency } \\
\text { (respondents) }\end{array}$ & 329 & 171 & 500 \\
\hline & Proportion (\%) & 65.8 & 34.2 & 100.0 \\
\hline \multirow{2}{*}{$\begin{array}{l}\text {. Unsustainable development of rural areas is } \\
\text { damaging the landscape. }\end{array}$} & $\begin{array}{c}\text { Frequency } \\
\text { (respondents) }\end{array}$ & 451 & 49 & 500 \\
\hline & Proportion (\%) & 90.2 & 9.8 & 100.0 \\
\hline \multirow{2}{*}{$\begin{array}{l}\text { - The importance of agricultural amenities, } \\
\text { such as landscape values, will increase in the } \\
\text { future compared to today. }\end{array}$} & $\begin{array}{c}\text { Frequency } \\
\text { (respondents) }\end{array}$ & 441 & 59 & 500 \\
\hline & Proportion (\%) & 88.2 & 11.8 & 100.0 \\
\hline
\end{tabular}

The results in the above correspond to the previous research which revealed that the role and function expected from agriculture and rural areas in the future, ensuring the stable supply of foodstuff, is decreasing, whereas the expectation regarding 'landscape preservation' and 'tourism and vacation' is increasing [53,54]. It seems that most of the public considers the environment, nature, and culture as important factors determining the quality of an individual's life [55]. Hence, it can be predicted that as the national income level increases, the demand for agriculture and rural areas as a space for leisure, recreation, and rest combined with amenities such as landscape resources will also expand.

Subsequent questions were concerned with the APV policy. When detailed information about renewable energy policy and APVs was provided to the respondents, as in Figure 1 in Section 2.1, and the importance of renewable energy expansion policy was questioned, $67.4 \%$ (337 respondents) answered 'important,' and 11.2\% (56 respondents) answered 'not important' (Table 7).

On the question of whether the expansion of APV power plants damages the agricultural landscape, $60.6 \%$ (303 respondents) of all respondents answered 'yes,' whereas $39.4 \%$ (197 respondents) answered 'no' (Table 8). 
Table 7. Importance of renewable energy expansion policy.

\begin{tabular}{cccccccc}
\hline Classification & $\begin{array}{c}\text { Not at All } \\
\text { Important }\end{array}$ & $\begin{array}{c}\text { Not } \\
\text { Important }\end{array}$ & Neutral & Important & $\begin{array}{c}\text { Very } \\
\text { Important }\end{array}$ & Total & Average \\
\hline $\begin{array}{c}\text { Frequency } \\
\text { (respon- } \\
\text { dents) }\end{array}$ & 15 & 41 & 107 & 273 & 64 & 500 & 3.13 \\
$\begin{array}{c}\text { Proportion } \\
(\%)\end{array}$ & 3.0 & 8.2 & 21.4 & 54.6 & 12.8 & 100.0 & \\
\hline
\end{tabular}

The average was calculated by assigning points as follows: Not at all important $=1$ point; Not important $=2$ points; Neutral $=3$ points; Important $=4$ points; Very important $=5$ points.

Table 8. Whether the expansion of APVs damages agricultural landscape.

\begin{tabular}{cccc}
\hline Classification & Yes & No & Total \\
\hline Frequency (respondents) & 303 & 197 & 500 \\
Proportion (\%) & 60.6 & 39.4 & 100.0 \\
\hline
\end{tabular}

Table 9 presents the results of the cross-tabulation analysis on the importance of renewable energy expansion policy by grouping the respondents into those who answered 'yes' to the question in Table 8 and those who answered 'no.'

Table 9. Cross-tabulation results of whether APVs damage agricultural landscape and the importance of renewable energy expansion policy.

\begin{tabular}{|c|c|c|c|c|c|c|c|c|}
\hline \multicolumn{2}{|c|}{ Classification } & \multirow{2}{*}{$\begin{array}{c}\begin{array}{c}\text { Not at } \\
\text { All Im- } \\
\text { portant }\end{array} \\
13\end{array}$} & \multirow{2}{*}{$\begin{array}{c}\begin{array}{c}\text { Not } \\
\text { Important }\end{array} \\
38\end{array}$} & \multirow{2}{*}{$\begin{array}{c}\text { Neutral } \\
75\end{array}$} & \multirow{2}{*}{$\begin{array}{c}\text { Important } \\
147\end{array}$} & \multirow{2}{*}{$\begin{array}{c}\begin{array}{c}\text { Very } \\
\text { Important }\end{array} \\
30\end{array}$} & \multirow{2}{*}{$\begin{array}{c}\text { Total } \\
303\end{array}$} & \multirow{2}{*}{$\begin{array}{c}\text { Average } \\
\\
3.5\end{array}$} \\
\hline Yes & $\begin{array}{c}\text { Frequency } \\
\text { (respon- } \\
\text { dents) }\end{array}$ & & & & & & & \\
\hline & $\begin{array}{l}\text { Proportion } \\
\quad(\%)\end{array}$ & 4.3 & 12.5 & 24.8 & 48.5 & 9.9 & 100.0 & \multirow{3}{*}{3.9} \\
\hline \multirow[t]{2}{*}{ No } & $\begin{array}{l}\text { Frequency } \\
\text { (respon- } \\
\text { dents) }\end{array}$ & 2 & 3 & 32 & 126 & 34 & 197 & \\
\hline & $\begin{array}{l}\text { Proportion } \\
(\%)\end{array}$ & 1.0 & 1.5 & 16.2 & 64.0 & 17.3 & 100.0 & \\
\hline
\end{tabular}

Among the total number of respondents (303 respondents) from the group agreeing, $58.4 \%$ (177 respondents) answered that the renewable energy expansion policy is important, and $16.8 \%$ (51 respondents) answered 'not important.' Among the total number of respondents (197 respondents) from the group disagreeing, 81.3\% (160 respondents) answered that the renewable energy expansion policy is important, and $2.5 \%$ (five respondents) answered 'not important.' This result implies that the perception of the importance of renewable energy expansion policy is affected by the perception of whether the APVs damage the agriculture landscape.

\subsection{The Effect of APV Power Plants on the Amenity Value of Agricultural Landscape}

The multinomial logit model was employed to analyze the effect of APV power plants on the amenity value of agricultural landscape. Explanatory variables representing the accommodation attribute shown in Equation (5) in Section 2.2.2 were coded as follows. For the rural view attribute $\left(X_{i j}\right.$ landscape $)$, the 'solar panel view' was given 0 , and the 'farmland view' was given 1 . For the in-room amenities attribute $\left(X_{i j}\right.$ convenience $)$, 'low' was given 1 , 'moderate' was given 2 , and 'high' was given 3 . For cleanliness of the room $\left(X_{i j}\right.$ cleanliness $)$, 'average' was given 1 , 'clean' was given 2, and 'very clean' was given 3. 
Table 10 presents the estimated results for the rural tourism accommodation attribute. All the part-worth of each level of attributes attained statistical significance at the $1 \%$ level. The estimated coefficient of view type is positive which highlights that the respondents placed a higher value on the 'farmland view' than the 'solar panel view.' In-room amenities and cleanliness level also revealed a positive correlation, indicating that the respondents placed a higher value as the number of amenities and cleanliness increase. As for the price attribute, the coefficient value was negative, which corresponds to the economic theory that the marginal utility decreases with an increase in price (i.e., negative slope of demand curve with respect to price).

Table 10. Estimated results of the multinomial logit model.

\begin{tabular}{cccc}
\hline Variable & Coefficient & Std. Error & Z-Statistic \\
\hline View type & $1.1382^{* * *}$ & 0.0595 & 19.1348 \\
In-room amenities & $0.2892^{* * *}$ & 0.0362 & 7.9978 \\
Cleanliness & $0.2115^{* * *}$ & 0.0352 & 6.0135 \\
Price & $-0.0000^{* * *}$ & 0.0000 & -16.8284 \\
Constant & $-0.8469^{* * *}$ & 0.1535 & -5.5192 \\
\hline
\end{tabular}

*** denotes coefficients are significant at $1 \%$ level.

The MWTP for a change in the attribute level of accommodation during rural tourism is presented in Table 11. Equation (5) was used to derive the MWTP for each attribute, and the MWTP for 'farmland view' was estimated as USD 64.37. For the case of in-room amenities, the MWTP, when the level changed from 'low' to 'moderate' and 'moderate' to 'high,' was USD 16.35. In terms of cleanliness of the room, MWTP, when the level changed from 'average' to 'clean' and 'clean' to 'very clean,' was estimated as USD 11.96. When the relative size of MWTP for each attribute is compared, the MWTP for the type of view was the highest, thereby showing that when selecting accommodation for rural tourism, the respondents place the highest value on the view of the room.

Table 11. Marginal willingness-to-pay (MWTP) for each attribute.

\begin{tabular}{ccc}
\hline Variable & Changes in Level & $\begin{array}{c}\text { Marginal Willingness-to-Pay } \\
\text { (MWTP) }\end{array}$ \\
\hline View type & Solar panel view $\rightarrow$ Farmland view & $\$ 64.37($ KRW 75,882) \\
In-room amenities & Low $\rightarrow$ Moderate $\rightarrow$ High & $\$ 16.35($ KRW 19,279) \\
Cleanliness & Average $\rightarrow$ Clean $\rightarrow$ Very clean & $\$ 11.96($ KRW 14,097) \\
\hline
\end{tabular}

Furthermore, a comparative analysis of MWTP was conducted for sub-groups of respondents classified as (A) and (B) in Table 12 to analyze the effects of APVs on the public benefit function of agriculture which includes the agricultural landscape. (A) is the result of MWTP estimates based on the separated samples into those who answered 'yes' and those answered 'no' to the question of whether the expansion of APVs damages the agricultural landscape.

The analysis results revealed that the MWTP for the group that answered 'yes' is USD 86.12. On the other hand, the group that answered 'no' is USD 41.53. This result demonstrates that there is a difference between the MWTP depending on the awareness of the damaging effect of APVs on the agricultural landscape.

We also divided the respondents according to their perception of relative importance between the two policies, the public benefit direct payment and the expansion of renewable energy. Specifically respondents who deemed the importance of public functionality higher were categorized into the 'public value' group, and in the opposite case, the respondents were categorized into the 'renewable energy' group. When the importance was deemed equal by the respondents, they were categorized into a neutral group and were not included in this analysis. The MWTP for each group was analyzed and compared in (B) of 
Table 12. The MWTP in the group that place a higher value on the public benefit function of agriculture than the renewable energy expansion policy was estimated to be USD 86.97. In contrast, MTWP in the group that place a higher value on the renewable energy expansion policy was USD 31.47. This indicates that there is a difference between the MWTP subject to the perception to the relative importance of the policies.

Table 12. MWTP for each attribute based on the awareness of APVs.

\begin{tabular}{|c|c|c|c|c|c|c|}
\hline \multirow{3}{*}{ Variable } & \multirow{3}{*}{ Changes in Level } & \multicolumn{5}{|c|}{ MWTP } \\
\hline & & \multirow[t]{2}{*}{ Total } & \multicolumn{2}{|c|}{$\begin{array}{l}\text { The Damaging } \\
\text { Effect of APVs on } \\
\text { the Agricultural } \\
\text { Landscape (A) }\end{array}$} & \multicolumn{2}{|c|}{$\begin{array}{c}\text { Relative Importance } \\
\text { Between the Policies (B) }\end{array}$} \\
\hline & & & Yes & No & $\begin{array}{l}\text { Public } \\
\text { Value }\end{array}$ & $\begin{array}{c}\text { Renewable } \\
\text { Energy }\end{array}$ \\
\hline \multirow{3}{*}{ View type } & \multirow{3}{*}{$\begin{array}{c}\text { Solar panel } \\
\text { view } \rightarrow \text { Farmland view }\end{array}$} & $\$ 64.37$ & $\$ 86.12$ & $\$ 41.53$ & $\$ 86.97$ & $\$ 31.47$ \\
\hline & & (KRW & (KRW & (KRW & (KRW & (KRW \\
\hline & & $75,882)$ & $101,518)$ & $48,958)$ & $102,517)$ & $37,097)$ \\
\hline \multirow{3}{*}{$\begin{array}{l}\text { In-room } \\
\text { amenities }\end{array}$} & \multirow{3}{*}{ Low $\rightarrow$ Moderate $\rightarrow$ High } & $\$ 16.35$ & $\$ 13.66$ & $\$ 19.06$ & $\$ 12.60$ & $\$ 20.02$ \\
\hline & & (KRW & (KRW & (KRW & (KRW & (KRW \\
\hline & & $19,279)$ & $16,100)$ & $22,463)$ & $14,855)$ & $23,595)$ \\
\hline \multirow{3}{*}{ Cleanliness } & \multirow{3}{*}{$\begin{array}{c}\text { Average } \rightarrow \text { Clean } \rightarrow \text { Very } \\
\text { clean }\end{array}$} & $\$ 11.96$ & $\$ 11.98$ & $\$ 11.81$ & $\$ 10.47$ & $\$ 10.35$ \\
\hline & & (KRW & (KRW & (KRW & (KRW & (KRW \\
\hline & & $14,097)$ & $14,116)$ & $13,916)$ & $12,340)$ & $12,199)$ \\
\hline
\end{tabular}

The estimated results of MWTP from the CE model suggests that APVs have the decreasing effects on the value of the agricultural landscape. Moreover, this holds true even for the respondents who consider that 'APV power plants do not damage the agricultural landscape' and that the 'expansion of renewable energy' is more important than the public benefit function of agriculture.

Table 13 presents the estimated results of the impact of APVs on the amenity value of the agricultural landscape. The total decreasing value of the agricultural landscape for the expansion of APV power plants in farmlands across the country is estimated approximately USD 1.70 billion per annum. To calculate the impact of APV power plants on the value of the agricultural landscape in monetary terms, we multiplied the MWTP and the number of overnight rural tours obtained from the Rural Development Administration [39]. The MWTP is the price that the individual is willing to pay for one-time rural tourism. Hence, to estimate the effect on the value of the agricultural landscape in a monetary unit, the MWTP of USD 64.37 was multiplied by the total number of overnight rural tours. This indicates that the agricultural landscape value decreases by $55.0 \%$ of the total estimated agricultural amenity value (USD 73.20 billion) in Korea [56]. A more realistic estimation would be feasible using the area size where APV power plants can be installed. If all of the $42.1 \%$ of 'farmland that agreed to be APVs (very agree + agree),' as surveyed in [6], install APV power plants, the value of the agricultural landscape will decrease by USD 713.76 million.

Table 13. The impact of APV expansion on the value of agricultural landscape.

\begin{tabular}{ccc}
\hline Classification & Estimate Result & Calculation \\
\hline $\begin{array}{c}\text { Impact on the } \\
\text { agricultural landscape }\end{array}$ & $\begin{array}{c}\text { Approximately } \$ 1.70 \text { billion } \\
\text { (KRW } 1.9 \text { trillion) }\end{array}$ & $\begin{array}{c}\text { Number of overnight rural } \\
\text { tours }\end{array}$ \\
& $\times$ MWTP (KRW/night) \\
\hline
\end{tabular}

\section{Discussion}

This research surveyed the public awareness of agricultural landscape resources and APV power plants given the potential trade-off between the expansion of APV systems as part of the renewable energy policy and the enhanced policy support for the public benefit function of agriculture. The CE method was applied to analyze the effect of APV expansion on the value of agricultural landscape. 
Major results derived from the awareness survey are as follows. When asked how important agricultural landscape is to the respondents, $87.0 \%$ (435 respondents) answered 'important,' and only $0.8 \%$ (4 respondents) answered 'not important.' Moreover, when asked whether the importance of the agricultural landscape may increase in the future compared to today, $88.2 \%$ (441 respondents) answered 'yes.' This corresponds to the findings from a number of previous research [53,54,57] that an increasing proportion of individuals consider the expected role of agriculture to be 'maintaining landscape and providing a place for tour and leisure' rather than 'a source of stable supply of food.' When asked whether the expansion of APVs may damage the agricultural landscape, 60.6\% (303 respondents) of the total respondents answered 'yes,' and 39.4\% (197 respondents) answered 'no.'

The CE method was employed to analyze the effect of APV expansion on the amenity value of the agricultural landscape. The MWTP for 'farmland view' in comparison to 'solar panel view' was found to be USD 64.37, which can be interpreted as the damaged value of agricultural landscape when the general farmland view is changed to a solar panel view. Moreover, with the amendment of the Farmland Act, if APV power plants are disseminated throughout the country, including the agricultural promotion areas, the value of agricultural landscape is expected to decline by a total of USD 1.70 billion. Hence, it can be concluded that the expansion of APV power plants has a negative impact on the agricultural landscape.

Expansion of renewable energy and the public benefit function of agriculture are two essential polices at the national level. The further installation of APVs can be a solution to obtaining renewable energy as well as increasing farm household income. The likely consequence of the government failing to recognize the potential trade-off between the two policies would be aggravated conflicts between the policy objectives. In such a case, it may incur various costs such as societal problems, environmental costs as well as the direct damages. The installation of large-scale solar panels is influenced by concerns over landscape, ecosystem, and the use of arable and underground water supply. Moreover, there could be a potential trade-off between renewable energy supply and public value, such as environmental and landscape preservation from APVs [9]. The results in this paper are the empirical results that suggest such concerns can be actually realized. The expansion of APVs in agricultural promotion areas through the amendment of the Farmland Act may be against the trends of the era. As the expansion of APVs involves a potential trade-off between the two policy goals of the renewable energy expansion and public benefit functions of agriculture, the policy decisions need to be made cautiously considering the relationship.

There is a broad consensus on the need to find renewable alternatives to meet growing energy demand [58]. However, the utilization of arable agricultural land for the production of energy remains controversial [23]. Numerous assessments have been made on almost all types of renewable energy including APVs, but such studies have focused primarily on technical, environmental and economic issues. On the other hand, the impact of the expansion of renewable energy on landscapes or local communities has hardly been assessed.

The public demand for agricultural lands and rural areas as spaces for leisure, recreation and rest is expected to increase in the future. Under this context, the results of this analysis show that, despite the technological and economic advantages provided by renewable energy, its detrimental impact on the value of the agricultural landscape may offset the positive effects of APVs. Therefore, along with a systematic and in-depth assessment of the impact of APVs on agricultural landscape and land use, a thorough analysis on the compatibility is also needed.

New technological systems, such as APVs, may be rejected by community members for the perceived damaging effect on the landscape and land use despite their technical and economic advantages. In the case of Korea, the installation of APV solar panels on farmlands so far solely used for agricultural production is triggering a serious conflict among local residents. Such conflicts can inflict further damage on the maintenance and formation of local communities. Therefore, it is necessary to engage and communicate 
with community members as well as policy makers, scientists, and engineers from the early stages of the development of renewable energy technologies and designing of related policies. Moreover, a multifaceted assessment of the acceptability and applicability of the local community members should be simultaneously conducted.

Last but not least, the APVs must be installed based on a technological approach that can improve the sustainability of agriculture and the APV expansion policy should be promoted in a way that can meet the future demands of energy and food consumption while making a contribution to the multi-functionality of agriculture.

\section{Conclusions}

The purpose of this study is to analyze the impact of the expansion of the APV power plants on the agricultural landscape. For this purpose, we conducted a survey on the public awareness of the APV power plants. We then analyzed the effect of APV power plants on agricultural landscape value based on the choice experiment method. Based on the results, this study assessed the trade-offs between the renewable energy expansion policy and the agricultural policy to expand the multi-functionality of agriculture and presented policy implications.

This study has an academic contribution in that it is the first study to empirically analyze the impact of the APV power plants on the value of agricultural landscape. The results of the empirical analysis present that APV projects promoted as part of the renewable energy expansion policy involve a trade-off with the public function of agriculture such as the agricultural landscape. A further study with an in-depth analysis of the local community's acceptability and the applicability of renewable energy technologies such as APVs seems necessary. We leave this as a future research topic.

Author Contributions: Conceptualization, T.-H.K. and S.-R.Y.; methodology, T.-H.K. and K.-S.C.; validation, T.-H.K. and K.-S.C.; investigation (data and evidence collection), T.-H.K. and K.-S.C.; writing-original draft preparation, T.-H.K., K.-S.C. and S.-R.Y.; writing-review and editing, T.-H.K. and S.-R.Y.; supervision, S.-R.Y. All authors have read and agreed to the published version of the manuscript.

Funding: This research received no external funding.

Data Availability Statement: Data sharing not applicable.

Conflicts of Interest: The authors declare no conflict of interest.

\section{References}

1. Mankiw, N.G. Principles of Economics, 8th ed.; Cengage Learning: San Francisco, CA, USA, 2018.

2. Kim, D.H.; Lee, S.H.; Ha, J.Y.; Seo, J.B. Comparative study of agrophotovoltaics perception between the solar PV farm and non-solar PV farm. In Proceedings of the KAAFP 2018 Summer Annual Conference, Suncheon, Korea, 17 August 2018.

3. Ministry of Trade, Industry and Energy. Renewable Energy 3020 Implementation Plan; MOTIE: Sejong, Korea, 2017.

4. Byeon, J.Y. Analysis of Rural Solar Power Project to Improve Farm Income; National Assembly Budget Office: Seoul, Korea, 2021.

5. Kim, Y.J.; Seo, D.S.; Heo, J.H.; Lee, J.M. Net Zero: Issues and Challenges of Rural Solar Power; Korea Rural Economic Institute: Naju, Korea, 2021.

6. Kim, Y.J.; Kim, S.S.; Chae, G.S.; Seo, D.S.; Park, J.Y.; Song, S.H.; Choo, S.M. Study on Challenges Faced by the Supply of Rural Solar Energy and an Improvement Plan; Korea Rural Economic Institute: Naju, Korea, 2018.

7. Seo, L. Heated Discussions on the Installation of 'Agrophotovoltaic' Power Plant System in Agriculture Promotion AreasThe Farmers Newspaper. 30 October 2020. Available online: https://www.nongmin.com/news/NEWS/POL/ETC/328390/view? site_preference=normal (accessed on 1 November 2020).

8. Wikipedia. Available online: https:/ / en.wikipedia.org/wiki/Agrivoltaic (accessed on 24 July 2021).

9. Murdock, H.E.; Gibb, D.; Andre, T.; Sawin, J.L.; Brown, A.; Ranalder, L.; Collier, U.; Dent, C.; Epp, B.; Hareesh Kumar, C.; et al. Renewables 2021: Global Status Report; REN21 Secretariat: Paris, France, 2021.

10. Sacchelli, S.; Garegnani, G.; Geri, F.; Grilli, G.; Paletto, A.; Zambelli, P.; Ciolli, M. Trade-off between photovoltaic systems installation and agricultural Practices on arable lands: An environmental and socio-economic. Land Use Policy 2016, 56, 90-99. [CrossRef]

11. Lim, C.H.; Gim, G.H.; Lee, S.H.; Nam, J.W.; Jang, Y.S.; Lee, S.R. Analysis of national and global agro-photovoltaic power plant system implementation trend and the value chain. J. Korean Sol. Energy Soc. 2018, 16, 31-38.

12. Weselek, A.; Ehmann, A.; Zikeli, S.; Lewandowski, I.; Schindele, S.; Högy, P. Agrophotovoltaic systems: Applications, challenges, and opportunities. A review. Agron. Sustain. Dev. 2019, 34, 1-20. [CrossRef] 
13. Pascaris, A.S.; Schelly, C.; Pearce, J.M. A first investigation of agriculture sector perspectives on the opportunities and barriers for agrivoltaics. Agronomy 2020, 10, 1885. [CrossRef]

14. Toledo, C.; Scognamiglio, A. Agrivoltaic systems design and assessment: A critical review, and a descriptive model towards a sustainable landscape vision (three-dimensional agrivoltaic patterns). Sustainability 2021, 13, 6871. [CrossRef]

15. Yu, Y.; Ko, Y. A Review of the Attributes of Successful Agriphotovoltaic Projects. In Proceedings of the 4th APRU Sustainable Cities and Landscapes PhD Symposium 2020, Auckland, New Zealand, 14 December 2020.

16. Kim, M.S.; Kang, M.Y.; Kim, J.S.; Lee, Y.H.; Jung, J.S.; Son, J.G.; Song, K.O.; Jeon, H.I.; Kim, C.G.; Park, S.H.; et al. The Effect of System Connected Advancement of Agro-photovoltaic on the Cultivation of Rice and the Increase in the Income of Rural Household. In Proceedings of the 2017 Autumn Annual Conference on Korean Society of Crop Science, Muju, Korea, 20 October 2017.

17. Son, H.C.; Park, H.J.; Kim, Y.S. Economic analysis of Korean agro-photovoltaics power generation. J. Reg. Stu. 2019, $27,1-12$.

18. Schindele, S.; Trommsdorff, M.; Schlaak, A.; Obergfell, T.; Bopp, G.; Reise, C.; Braun, C.; Weselek, A.; Bauerle, A.; Högy, P.; et al. Implementation of agrophotovoltaics: Techno-economic analysis of the price-performance ration and its policy implications. Appl. Energy 2020, 265, 114737. [CrossRef]

19. Cho, Y.S.; Shin, G.H.; Kim, H.G.; Kim, S.J.; Son, D.M. Growth and Quality Characteristics under APV(AgriPhotoVoltaics) in Autumn Chinese Cabbage (Brassica campestris subsp. napus var. pekinensis) and Cabbage (Brassica oleracea var. capitata) . In Proceedings of the 2019 KSES Autumn Annual Conference, Jecheon, Korea, 18 October 2019.

20. Yoon, C.Y.; Ahn, K.N.; Jeong, B.D.; Kim, S.G.; Cho, J.I. Characteristics of Corn under Mimic APV Module Structure in Naju. In Proceedings of the 2019 KSES Autumn Annual Conference, Jecheon, Korea, 18 October 2019.

21. Yoon, C.Y.; Ahn, K.N.; Kang, S.J.; Kim, S.G.; Cho, J.I. Characteristics of Sesame under Mimic APV Module Structure in Naju. In Proceedings of the 2019 KSES Autumn Annual Conference, Jecheon, Korea, 18 October 2019.

22. Kim, S.; Kim, S.; Yoon, C.Y. An efficient structure of an agrophotovoltaic system in a temperate climate region. Agronomy 2021, 11, 1584. [CrossRef]

23. Ketzer, D. Land Use Conflicts between Agriculture and Energy Production: Systems Approaches to Allocate Potentials for Bioenergy and Agrophotovoltaics. Doctoral Dissertation, Stockholm University, Stockholm, Sweden, 2020.

24. Trommsdorff, M. Agrivoltaics: Opportunities for Agriculture and the Energy Transition; Fraunhofer Institute for Solar Energy System ISE, Ed.; Fraunhofer Institute for Solar Energy System ISE: Freiburg, Germany, 2020.

25. Zoellner, J.; Schweizer-Ries, P.; Wemheuer, C. Public acceptance of renewable energies: Results from case studies. Energy Pol. 2008, 36, 4136-4141. [CrossRef]

26. Lancaster, K.J. A new approach to consumer theory. J. Pol. Econ. 1996, 74, 132-157. [CrossRef]

27. Choi, A.S.; Eom, Y.S. Measuring economic values of amenity services from urban greenspaces in the Seoul metropolitan area using choice experiment. Environ. Resour. Econ. Rev. 2018, 27, 105-138.

28. Louviere, J.J.; Hensher, D.A. On the design and analysis of simulated choice or allocation experiments in travel choice modeling. Transp. Res. Rec. 1982, 890, 11-17.

29. Louviere, J.J.; Woodworth, G. Design and analysis of simulated consumer choice and allocation experiments: An approach based on aggregate data. J. Mark. Res. 1983, 20, 350-367. [CrossRef]

30. Morley, C.L. Experimental destination choice analysis. Annu. Tour. Res. 1994, 21, 780-791. [CrossRef]

31. Adamowicz, W.; Boxall, P.; Williams, M.; Louviere, J. Stated preference approaches for measuring passive use values: Choice experiments and contingent valuation. Am. J. Agric. Econ. 1998, 80, 64-75. [CrossRef]

32. Hensher, D.A.; Rose, J.M.; Greene, W.H. Applied Choice Analysis: A Primer; Cambridge University Press: Cambridge, UK, 2005.

33. Kwon, O.S.; Lim, Y.A.; Kim, W.H. Economic values of recreational water: Rafting on the Hantan River. Environ. Resour. Econ. Rev. 2007, 16, 427-449.

34. Choi, A.S. Nonmarket values of major resources in the Korean DMZ areas: A test of distance decay. Ecol. Econ. 2013, 88, 97-107. [CrossRef]

35. Jung, H.H. Valuing amenity attributes of farm village using choice experiment-valuing rurality. J. Korean Soc. Rural Plan 2014, 20, 243-251. [CrossRef]

36. Lyu, S.O. A comparison of economic valuation Methods for tourism and recreation resources: Focusing on stated preference choice method(SPCM). J. Tour. Stu. 2014, 26, 105-125.

37. Yang, S.B.; Yang, S.R. The willingness-to-pay price for Makgeolli made of domestic rice. Korean J. Food Market. Econ. 2011, 28, 57-77.

38. Kim, T.H.; Yang, S.R. Economic value assessment of the agricultural amenities. Korean J. Agric. Manag. Policy 2019, 46, 640-667. [CrossRef]

39. Kim, K.H.; Hwang, D.Y.; Chae, H.S.; Ahn, O.S.; Lee, H.Y. A Fact-Finding Survey on Rural Tourism 2018; Lee, C.I., Kim, M.H., Eds.; National Institute of Agricultural Sciences: Wanju, Korea, 2019; ISBN 9788948061109.

40. Jung, J.W.; Lee, W.S.; Song, M.K.; Moon, J.H. A study on the attribute of rural tourism using the choice experiment. Korean J. Hosp. Tour. 2020, 29, 199-211. [CrossRef]

41. Bennett, J.; Adamowicz, V. Some Fundamentals of Environmental Choice Modelling. In The Choice Modelling Approach to Environmental Valuation; Bennett, J., Blamey, R., Eds.; Edward Elgar Publishing, Inc.: Northampton, MA, USA, 2001 ; pp. 37-69.

42. Kwak, S.J.; Yoo, S.H.; Chang, J.I. Valuing the Han-river estuary: Using conjoint analysis. Korean Econ. Assoc. $2006,54,141-161$.

43. Lewis, R.C. Isolating differences in hotel attributes. Cornell Hotel. Restaur. Adm. Q. 1984, 25, 64-77. [CrossRef] 
44. Knutson, B.J. Ten laws of customer satisfaction. Cornell Hotel. Restaur. Adm. Q. 1988, 29, 14-17. [CrossRef]

45. Kang, P.N. A study on the rural-tour destination preference of resident in Gwangju. J. Korean Urban Manag. Ass. $2005,18,3-21$.

46. Rambonilaza, M.; Dachary-Bernard, J. Land-use planning and public preferences: What can we learn from choice experiment method? Land. Urban. Plan. 2007, 83, 318-326. [CrossRef]

47. Lee, S.H.; Ryu, S.Y. A study on the differences in preference of accommodation attributes and experience activities by long-stay rural visitors' motivation. J. Tour. Sci. 2016, 40, 61-78.

48. Osti, L.; Ciceri, L. Tourists' perception of landscape attributes in rural tourism. Worldw. Hosp. Tour. Themes 2018, 10, 211-221. [CrossRef]

49. Häfner, K.; Zasada, I.; Van Zanten, B.T.; Ungaro, F.; Koetse, M.; Piorr, A. Assessing landscape preferences: A visual choice experiment in the agricultural region of Märkische Schweiz, Germany. Land. Res. 2018, 43, 846-861. [CrossRef]

50. Phelps, R.H.; Shanteau, J. Livestock judges: How much information can an expert use? Organ. Behav. Hum. Perf. 1978, 21, 209-219. [CrossRef]

51. Simon, H.A. Invariants of human behavior. Ann. Rev. Psy. 1990, 41, 1-9. [CrossRef] [PubMed]

52. Holmes, T.P.; Adamowicz, W.L. Attribute Based Methods. In A Primer on Nonmarket Valuation; Champ, P.A., Boyle, K.J., Brown, T.C., Eds.; Springer: Dordrecht, The Netherland, 2003; pp. 171-219.

53. Song, S.H.; Park, H.J. 2018 Public Opinion Survey on Agriculture and Rural Areas; Korea Rural Economic Institute: Naju, Korea, 2018.

54. Woo, B.J.; Chung, D.C.; Park, H.J. 2020 Public Opinion Survey on Agriculture and Rural Areas; Korea Rural Economic Institute: Naju, Korea, 2020.

55. Im, J.B. Trends and Implications of Agriculture Direct Payment Schemes in Major Developed Countries: Lessons and Tasks for Korean Public Payment Scheme. In Proceedings of the KAEA 2020 Annual Meeting, Seoul, Korea, 3 July 2020.

56. Yang, S.R.; Lim, S.T.; Yang, H.K.; Lee, C.S. The Value of Agriculture; Rural Development Administration: Wanju, Korea, 2012.

57. Heo, J.H.; Park, H.J.; Woo, B.J. 2019 Public Opinion Survey on Agriculture and Rural Areas; Korea Rural Economic Institute: Naju, Korea, 2019.

58. Jenner, S.; Chan, G.; Frankenberger, R.; Gabel, M. What drives states to support renewable energy? Energy J. 2012, 33 , 1-12. [CrossRef] 